\title{
SUSTAINABLE URBAN WEED CONTROL: EXPERIENCES OF NON-CHEMICAL WEED CONTROL (MANUAL LABOUR, MECHANICAL AND THERMAL-FLAME WEEDING) IN THE MUNICIPALITY OF OCCHIOBELLO, ITALY
}

\author{
FILIPPO MORETTO \& DAVIDE DI DOMENICO \\ Comune di Occhiobello \& Mellivora, Italy
}

\begin{abstract}
In the middle of 2015, prior than the mediatic debate on glyphosate in Italy, the Municipality of Occhiobello, aiming at fully implement the "sustainable use of pesticides - PAN fitosanitari" legislation, took the decision to definitely abandon chemical weed control in application of a precautionary principle. Uncontrolled weeds can cause problems on kerb channels and footways, damaging surface infrastructure and collecting litter. Adopting alternative methods to control weeds reduces the risks associated with herbicide use (e.g. storage, handling, use and disposal), but it can be costlier. Several areas of the municipal territory were treated with a non-chemical method and the results were assessed. Every involved area was classified according to the DEFRA (UK Department for Environment Food \& Rural Affairs) weed level scale criteria and species before the treatment, in order to clarify the initial level of weeds both in slabs and asphalt streets. Experimental results demonstrated the level of efficacy of each treatment and its cost-effective ratio, and it was possible to identify a simple and effective graphic indicative of the case-specific necessary treatment. New achievements are expected by the end of 2017 when a whole season of both steam and flame thermal control will be concluded.
\end{abstract}

Keywords: weeds, flame, non-chemical weed control, vapour, mechanical, herbicides, pesticides.

\section{INTRODUCTION}

The original contribution of this work is the identification of a simple indicator to determine directly on site, the treatments required in a determined situation to control weeds in urban areas avoiding chemical herbicides.

At the end of 2015, prior than the mediatic debate on glyphosate in Italy, the Municipality of Occhiobello, aiming at fully implement the "Sustainable use of pesticides PAN fitosanitari" legislation, took the decision to definitely abandon chemical weed control in application of the precautionary principle. Uncontrolled weeds can cause problems on kerb channels and footways, damaging surface infrastructure and collecting litter. Adopting alternative methods to control weeds reduces the risks associated with herbicide use (e.g. storage, handling, use and disposal), but it can be costlier. Several areas of the municipal territory were treated with non-chemical method and the results were assessed.

Before the treatment every area was classified according to the DEFRA (UK Department for Environment Food \& Rural Affairs) weed level scale criteria and species, in order to clarify the initial level of weeds both in slabs and asphalt streets. Experimental results demonstrated the level of efficacy of each treatment and its cost-effective ratio. Based on these first findings a new complete season of non-chemical weed control has been scheduled on 2017. 


\section{IMPLEMENTATION OF A STRATEGY OF NON-CHEMICAL WEED CONTROL}

The assessment of the herbicide effect of the applied methods has been determined following the DEFRA guidelines. In particular the initial and final level of weeds coverage was assessed according to DEFRA scale [1] for both slabs and asphalts in which the weed abundance is connected with a score as it follows.

\subsection{Flame and steam weeding application methods}

The carefully directed and controlled flame briefly passes over the weeds without charring them. Brief exposure to intense heat causes the cell sap to expand and that in turn, disrupts cell walls and interrupts the intracellular feed flow. Within hours weeds wilt and die due to continuous evaporation caused by seared cuticles [2].

Table 1: Weed level scale criteria. (Source: DEFRA [5] modified.)

\begin{tabular}{|l|l|l|l|l|l|}
\hline & & & Criteria 1 & Criteria 2 & Criteria 3 \\
\hline Level & Description & Score & Height $(\mathrm{mm})$ & $\begin{array}{l}\text { Weed diameter } \\
\text { or length (mm) }\end{array}$ & $\begin{array}{l}\text { Joint coverage } \\
(\%)\end{array}$ \\
\hline 1 & $\begin{array}{l}\text { No noticeable } \\
\text { weeds }\end{array}$ & $<3$ & $<10$ & $<50$ & $<10$ \\
\hline 2 & $\begin{array}{l}\text { Occasional } \\
\text { small weeds }\end{array}$ & $4-6$ & $10-50$ & $50-100$ & $0-20$ \\
\hline 3 & $\begin{array}{l}\text { Patchy weed } \\
\text { growth }\end{array}$ & $7-9$ & $50-100$ & $100-150$ & $20-30$ \\
\hline 4 & $\begin{array}{l}\text { Numerous } \\
\text { weeds }\end{array}$ & $10-12$ & $100-150$ & $150-200$ & $30-40$ \\
\hline 5 & $\begin{array}{l}\text { Numerous } \\
\text { large weeds }\end{array}$ & $13-15$ & $150-200$ & $200-300$ & $40-50$ \\
\hline 6 & $\begin{array}{l}\text { Excessive } \\
\text { weeds }\end{array}$ & $16-18$ & $>200$ & $>300$ & $>50$ \\
\hline
\end{tabular}

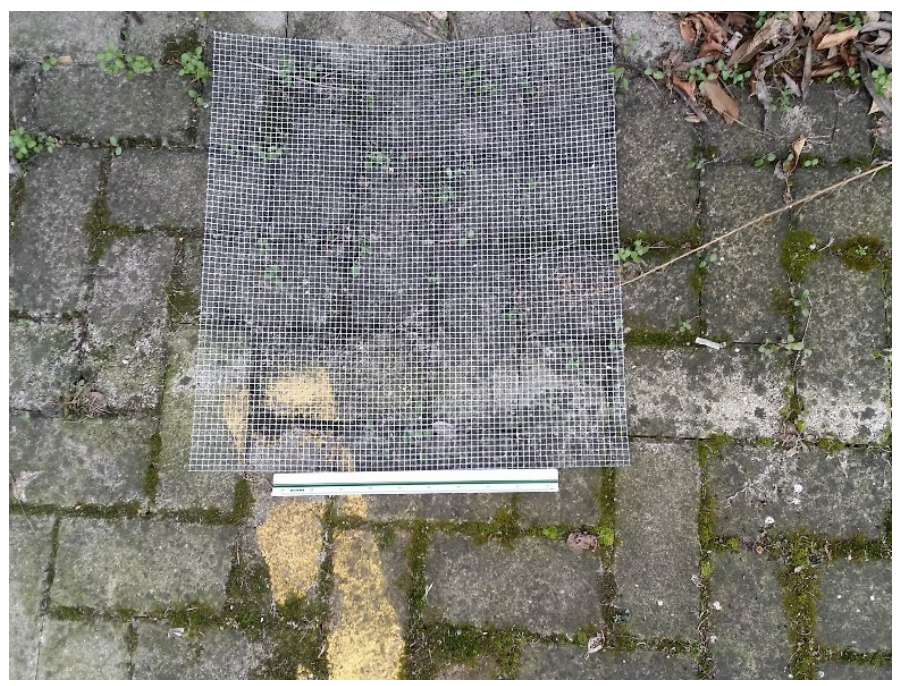

Figure 1: Quadrant for weed abundance assessment according to DEFRA method. 
Flame weeding does not actually cause weeds to burn, but it determines a change in pigmentation and the foliage green colour is highly enhanced. When successful the result of this treatment can be clearly seen some days after application with plants leaf yellowing. Proper application times must be determined so that the heat treatment can be effective. The producer of the used equipment underlines that if this method is used on plants at their early growth stage (20-25 days after emergence), it will only be necessary to apply heat at 90 $95^{\circ} \mathrm{C}$ for just one second in order to kill these seedlings. Apply heat at $101^{\circ} \mathrm{C}$ for one second on plants at other, more advanced growth stages. So, in practice it is necessary to apply surplus heat and to vary exposure time to heat of the plants to be flamed. In brief, we can assume a flaming time over the 'second' in order to safely use a temperature above $100^{\circ} \mathrm{C}$ on all plants. The average gas consumption was about $2-4 \mathrm{~kg} / \mathrm{h} \mathrm{LPG}$.

The Steam weeding system uses water, heated under pressure in a diesel fired boiler, pumped through a delivery hose to a nozzle. The nozzle has the effect of maintaining the pressure in the boiler allowing the water into saturated steam and superheated water at atmospheric pressure [3].

Delivery temperatures range from $98^{\circ} \mathrm{C}$ to $110^{\circ} \mathrm{C}$, with a soil penetration of up to nearly $5 \mathrm{~mm}$. The combination of saturated steam and boiling water creates a sudden increase in the temperature of the water within the plant's cells causing them to rapidly expand and rupture.

\subsection{Examples of typical flora}

The typical local flora can be described as in Table 2 [4].

Table 2: Examples of typical flora.

\begin{tabular}{|l|l|l|l|}
\hline Species & Common name & Species & Common name \\
\hline Artemisia vulgaris & Assenzio & Setaria viridis & Pabbio \\
\hline Cirsium arvense & Cardo & Cynodon dactylon & Gramigna \\
\hline Convolvulus arvensis & Convolvolo & Agropyron repens & Gramigna Comune \\
\hline $\begin{array}{l}\text { Sorghum Halepense } \\
\text { (and other Poaceae) }\end{array}$ & Sorghetta/Melghetta & Equisetum arvensis & Equiseto \\
\hline Poa annua & Fienarola & Portulaca selvatica & Porcellana Comune \\
\hline Hordeum murinum & Orzo Selvatico & Amarantus sp. & Amaranto \\
\hline Bromus sterilis & Forasacco & Taraxacum officinale & Dente di Leone \\
\hline Papaver rhoeas & Papavero & Plantago sp. & Piantaggine \\
\hline Sonchus oleaceus & Grespino Comune & Trifolium sp. & Trifoglio \\
\hline Polygonum avigolare & Centinodia & Lactuca serriola & Lattuga Selvatica \\
\hline Digitaria sanguinalis & Sanguinella & Polycarpon tetraphyllum & Migliarina \\
\hline
\end{tabular}




\subsection{Experiences}

After the first use of flame technique it was immediately clear that it requires well developed user instructions and a documented strategy in order to guarantee an effective result.

Difficulties were experienced in particular to:

1. define a common criterion to assess the level of weed abundance;

2. define the number of required treatment on a single area to be treated;

3. define whether an integrated strategy (e.g. with mechanical treatment) was required;

4. find an easy "user's manual" for operators

\subsection{Materials and methods}

A first set of experimental tests were followed in summer 2016. Several areas respectively named with a number $(1,2,3 \ldots)$ were considered. The experimental ratio of this first set of tests was the determination of areas to be treated, the determination of weed species, the evaluation of the level of weed presence according to Defra guidelines [1]. The equipment is listed as in Table 3.

\subsection{Test report}

The first tests were conducted (AREAS from 1 to 5) at an application time of flame weeding of $2 \mathrm{~m}^{2} * \mathrm{~min}^{-1}$ in order to follow the constructor indication of nearly 1 second per plant. More, the differential effect of flame weeding usage only and the integration between different techniques were tested. A second experimental phase (AREA 5) was delivered after the evaluation of this first set of tests by assessing the effect of different application time of both steam and flame weeding in a defined homogeneous area. Different durations of application were tested and in particular $2 \mathrm{~m}^{2} * \mathrm{~min}^{-1}, 1 \mathrm{~m}^{2} * \mathrm{~min}^{-1}, 0.5 \mathrm{~m}^{2} * \mathrm{~min}^{-1}$. Single and integrated weed control methods were assessed and the results are reported as it follows. The initial and final level of weed coverage was assessed on the base of DEFRA classification. Among the other the results of principal tested areas are listed as it follows in Table 4.

Table 3: Materials and methods for weeds control.

\begin{tabular}{|c|c|c|c|c|}
\hline Material & Manual labour & Flame & Steam & Street cleansing \\
\hline Description & $\begin{array}{c}\text { Weed scraper } \\
\text { Weed brush } \\
\text { Gasoline } \\
\text { Brush cutter }\end{array}$ & $\begin{array}{c}\text { Flame burner } \\
\text { model PC2 by } \\
\text { Officine Mengozzi } \\
\text { (Ferrara). }\end{array}$ & $\begin{array}{c}\text { Walkam steam } \\
\text { weeding machine }\end{array}$ & $\begin{array}{c}\text { A normal street } \\
\text { sweeper was used, } \\
\text { especially after } \\
\text { manual treatment } \\
\text { with the objective } \\
\text { of both removing } \\
\text { residues and } \\
\text { provide a brush } \\
\text { over the weed. }\end{array}$ \\
\hline
\end{tabular}


Table 4: Part a), b) and c) Presentation of the results of tests.

Part a)

\begin{tabular}{|l|l|l|l|}
\hline Area & 1 & 2 & 3 \\
\hline Type & Traffic island (LIDL) & $\begin{array}{l}\text { Traffic island (Gurzone } \\
\text { Roundabout) }\end{array}$ & $\begin{array}{l}\text { Place - Matteotti - via } \\
\text { Roma }\end{array}$ \\
\hline Surface & Cobbled stone & Cobbled stone & Slab and asphalt \\
\hline Weeds & $\mathrm{T}$ & $\mathrm{T}$ & $\mathrm{T}$ \\
\hline Treatment & $\mathrm{F}$ & $\mathrm{F}+\mathrm{Ma}$ & $\mathrm{F}+\mathrm{Ma}$ \\
\hline Application time & $2 \mathrm{~m}^{2} * \mathrm{~min}^{-1}$ & $2 \mathrm{~m}^{2} * \mathrm{~min}^{-1}$ & $2 \mathrm{~m}^{2} * \mathrm{~min}^{-1}$ \\
\hline Integration & $\mathrm{No}$ & Yes & Yes \\
\hline DEFRA 0 & 5 & 5 & 4 \\
\hline DEFRA 1 & 3 & 1 & 1 \\
\hline DEFRA 7 & 3 & 1 & 1 \\
\hline DEFRA 30 & $3-4$ & 3 & 3 \\
\hline $\begin{array}{l}\text { Repetition required } \\
\text { for effective control }\end{array}$ & $\begin{array}{l}\text { Every 3 weeks from } \\
\text { August to November }\end{array}$ & $\begin{array}{l}\text { Every 3 weeks from } \\
\text { August to November }\end{array}$ & $\begin{array}{l}\text { Every 2 weeks from } \\
\text { August to November }\end{array}$ \\
\hline Notes & & & \\
\hline
\end{tabular}

Part b)

\begin{tabular}{|l|l|l|l|}
\hline Area & 4 & 5/A & 5/B \\
\hline Type & Place Matteotti & $\begin{array}{l}\text { Urban riverbanks between P.za } \\
\text { Mazzini and P.za Matteotti }\end{array}$ & $\begin{array}{l}\text { Urban riverbanks } \\
\text { between P.za Mazzini } \\
\text { and P.za Matteotti }\end{array}$ \\
\hline Surface & Slabs & Cement and asphalt & Cement and asphalt \\
\hline Weeds & T & T + sorghum H. + Poaceae & $\begin{array}{l}\text { T + sorghum H. }+ \\
\text { Poaceae }\end{array}$ \\
\hline Treatment & Ma & F & F \\
\hline Application time & N.A. & $2 \mathrm{~m}^{2} * \min ^{-1}$ & $1 \mathrm{~m}^{2} * \mathrm{~min}^{-1}$ \\
\hline Integration & No & No & No \\
\hline DEFRA 0 & 4 & 5 & 5 \\
\hline DEFRA 1 & 1 & 3 & 3 \\
\hline DEFRA 7 & 1 & 2 & 2 \\
\hline DEFRA 30 & 3 & 2 & 1 \\
\hline $\begin{array}{l}\text { Repetition required } \\
\text { for effective control }\end{array}$ & $\begin{array}{l}\text { Every week from } \\
\text { August to November }\end{array}$ & -- & - \\
\hline Notes & & $\begin{array}{l}\text { AREA 5 it was divided into 6 } \\
\text { different portions of about 1 } \\
\text { square meter each. Every single } \\
\text { portion (A, B, C, D, E, F) was } \\
\text { treated with a specific method. }\end{array}$ & \\
\hline & & & \\
\hline
\end{tabular}


Table 4: Continued.

Part c)

\begin{tabular}{|c|c|c|c|c|}
\hline Area & $5 / \mathrm{C}$ & $5 / \mathrm{D}$ & $5 / \mathrm{E}$ & $5 / \mathrm{F}$ \\
\hline Type & $\begin{array}{l}\text { Urban riverbanks } \\
\text { between P.za Mazzini } \\
\text { and P.za Matteotti }\end{array}$ & $\begin{array}{l}\text { Urban riverbanks } \\
\text { between P.za } \\
\text { Mazzini and P.za } \\
\text { Matteotti }\end{array}$ & $\begin{array}{l}\text { Urban riverbanks } \\
\text { between P.za } \\
\text { Mazzini and P.za } \\
\text { Matteotti }\end{array}$ & $\begin{array}{l}\text { Urban riverbanks } \\
\text { between P.za } \\
\text { Mazzini and P.za } \\
\text { Matteotti }\end{array}$ \\
\hline Surface & Cement and asphalt & Cement and asphalt & Cement and asphalt & Cement and asphalt \\
\hline Weeds & $\begin{array}{l}\text { T + sorghum H. + } \\
\text { Poaceae }\end{array}$ & $\begin{array}{l}\text { T + sorghum H. + } \\
\text { Poaceae }\end{array}$ & $\begin{array}{l}\text { T + sorghum H. }+ \\
\text { Poaceae }\end{array}$ & $\begin{array}{l}\text { T + sorghum H. + } \\
\text { Poaceae }\end{array}$ \\
\hline Treatment & $\mathrm{F}$ & $\mathrm{S}$ & $\mathrm{S}$ & $\mathrm{S}$ \\
\hline Application time & $0.5 \mathrm{~m}^{2} * \mathrm{~min}^{-1}$ & $2 \mathrm{~m}^{2} \min ^{-1}$ & $1 \mathrm{~m}^{2} * \min ^{-1}$ & $0.5 \mathrm{~m}^{2} * \mathrm{~min}^{-1}$ \\
\hline Integration & No & No & No & No \\
\hline DEFRA 0 & 5 & 5 & 5 & 5 \\
\hline DEFRA 1 & 3 & 3 & 3 & 3 \\
\hline DEFRA 7 & 2 & 3 & 2 & 2 \\
\hline DEFRA 30 & 2 & 2 & 1 & $0-1$ \\
\hline $\begin{array}{l}\text { Repetition required } \\
\text { for effective control }\end{array}$ & $\begin{array}{l}\text { Every week from } \\
\text { August to November }\end{array}$ & -- & -- & \\
\hline Notes & & & & \\
\hline
\end{tabular}

Legenda:

$\mathrm{T}=$ typical prevalent weeds: Cynodon dactylon, Taraxacum officinale,

Cirsium arvense, Portulaca selvatica, Poa annua

$\mathrm{F}=$ flame weeding

$\mathrm{S}=$ steam weeding

$\mathrm{Me}=$ mechanical

$\mathrm{Ma}=$ manual labour

DEFRA $0=$ Initial weed level according to DEFRA [1] assessment method

DEFRA 1 = weed level at 1 day from the treatment according to DEFRA [1] assessment method

DEFRA 7 = weed level at 7 days from the treatment according to DEFRA [1] assessment method

DEFRA $30=$ weed level at 30 days from the treatment according to DEFRA [1] assessment method.

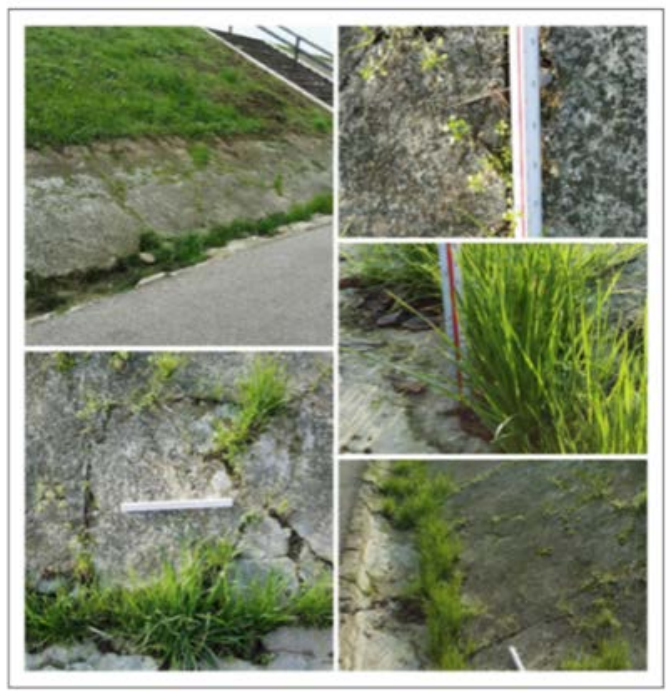

Figure 2: Visualization of area 5. 


\section{INTERPRETATION OF EXPERIMENTAL DATA AND CREATION OF A GRAPHIC INDEX FOR OPERATORS}

The idea behind the work presented in this paper, it was to verify the feasibility for different weed control methods and to assess its respective results. Above all, the most important objective was to develop a synthetic simple index to be used by the operators of urban hygiene practices.

Data were collected in order to understand:

1. The application time of every single treatment;

2. The intensity of application (always the maximum with flame and steam treatments);

3. The type and level of weed coverage;

4. The number of repetition along time.

This approach lead to some general considerations, such as for example:

1. The presence of Poaceae (such as Sorghum Halepense) determined the need for more intensity of treatment and more repetition;

2. With high level of DEFRA INDEX (from 4 to 6 ) a real change in weeds perception was obtained only with an integrated strategy (e.g. flame + mechanical treatments);

3. A real difference in plant growing is perceptible only from December to February.

For these reasons, a simple index to weed control was needed as a guideline for technical operators. A ternary diagram was developed connecting the aspects contributing to an efficient weed control of a specific area.

The three considered dimensions they were:

1. Weed coverage in terms of DEFRA INDEX [1] and type of plants;

2. Application time;

3. Efficacy (this dimension defines the necessity for one or more repeated treatment along time and eventual integration of one or more weeding techniques.)

In particular every point on the ternary plot represents a different "composition" of the three components. The concentration of each species is $100 \%$ (pure phase) in each corner of the triangle and $0 \%$ at the line opposite it. The percentage of a specific species decreases linearly with increasing distance from this corner. By drawing parallel lines at regular intervals between the zero line and the corner (as seen in the images), fine divisions can be established for easy estimation of the content of a species. For a given point, the fraction of each of the three characteristics in the composition of the service can be determined by the first.

The results of tests allowed the identification of three main areas in the plot.

\subsection{Black area}

- Initial Weed coverage: from 3 to 6 of DEFRA index

- Composition of weeds: perennials (Persistent, defy control through ability to regenerate from vegetative propagules and underground storage organs), Poaceae

- Indications: Integrated strategy is needed. A flame weeding intervention can be necessary in December, prior than the real vegetative season. After that, from March to late October a combination of steam, flame and mechanical control is needed for effective control (DEFRA level 1). It was verified that 8-9 flame weeding alternate to $4-5$ mechanical treatments were required in slab surfaces. The most effective "treatment speed" was the lowest one up to 2 minutes intervention per square meter. In case of faster treatment, the number of repetition must be increased up to a fortnightly base. 


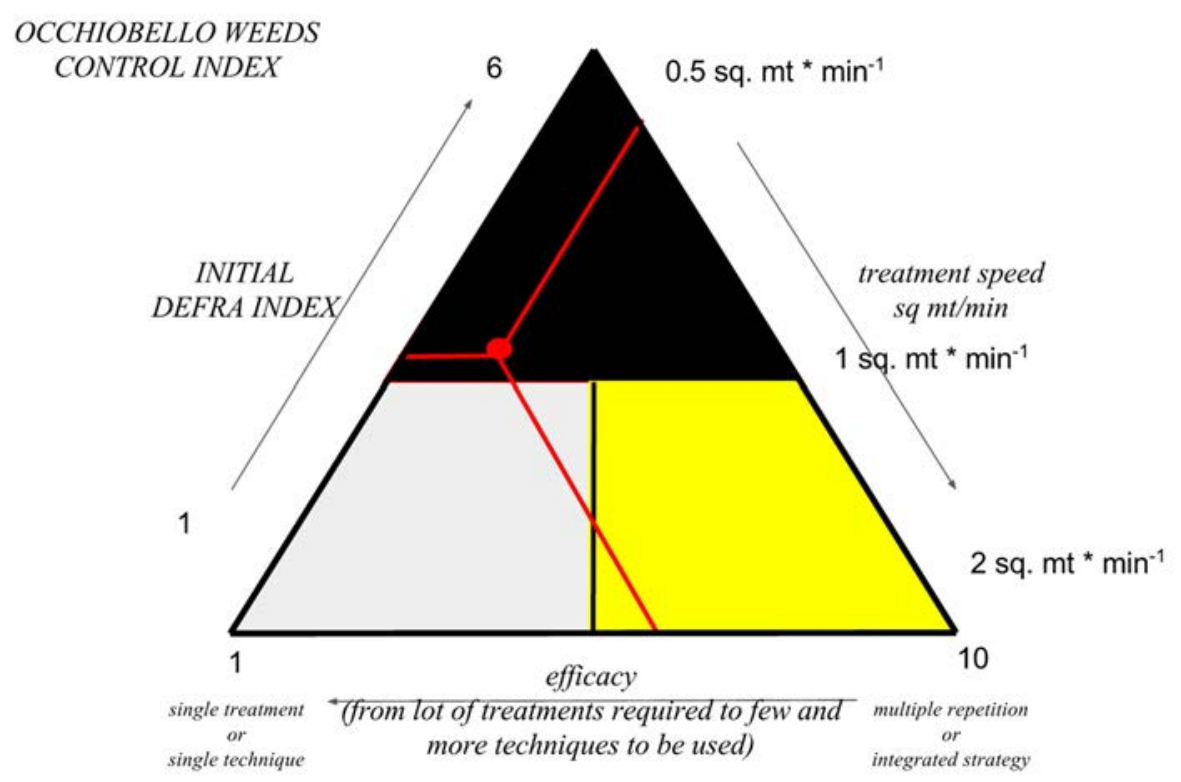

Figure 3: Occhiobello weed control index.

\subsection{Grey area}

- Initial Weed coverage: from 1 to 3 of DEFRA index

- Composition of weeds: annual broadleaf weeds

- Indications: Monitoring on a monthly base from March to late October. 4-5 flame or steam treatment can be required.

\subsection{Yellow area:}

- Initial Weed coverage: from 1 to 3 of DEFRA index

- Composition of weeds: annual broadleaf weeds and even perennials

- Indications: the area designs places in town that results from a prioritization of Municipality zones. It includes areas such as central plazas, Municipal courts, bike lines, hospital and other high frequented places. Monitoring on a weekly base from March to late October. in order to maintain a correct hygiene fast weekly treatment can be best solutions.

\section{CONCLUDING REMARKS}

There is a growing body of evidence concluding that herbicides and specifically glyphosate are not safe for our environment and pose significant risk to aquatic ecosystems, potable water supplies and human health [5]. For these reasons, the Municipality of Occhiobello (Italy) decided to reduce the environmental and health impact of its activities of weeds control and pest control. As results a number of non-chemical techniques for weeds control were tested aiming at evaluating their respective level of efficacy and efficiency and the eventual necessity for their integration. An easy to use indicator for operators was 
developed and new findings are expected for the late 2017 when a full program of integration between steam and flame weeds control and manual labour will be implemented.

\section{REFERENCES}

[1] UK Department for Environment Food \& Rural Affairs (Defra) - funded 5-year programme entitled: Development of zero and minimal herbicide regimes for controlling weeds on hard surfaces and determining their emissions PS2802 (20092015), Best Practice Guidance Notes for Integrated and Non-Chemical Amenity Hard Surface Weed Control, East Malling Research 2015, Online. http://www.emr.ac.uk/ wp-content/uploads/2015/03/BPWeeds2015web1.pdf

[2] Officine Mingozzi - Ferrara (Italy), How flame wedding works, Online. http://www.pirodiserbo.it/come-si-applica?lang=en Accessed on: 2 Feb. 2017.

[3] Rask, A.M., Non-chemical weed control on hard surfaces: An investigation of longterm effects of thermal weed control methods. Forest \& Landscape Research, (52), Forest \& Landscape Denmark, Frederiksberg, p. 156, 2012.

[4] Fazio, D., Giungla sull'asfalto. La flora spontanea delle nostre città, Blue Edizioni 2008.

[5] Winer, J., Holistic weed control practice for urban storm water catchments. Global trends, methods, limitations and cost benefits, Stormwater 2014. 3rd National Conference on Urban Water Management, pp. 13-17, 2014. 